\section{More central control}

British universities, which award degrees by examining their students, are now to be examined themselves.

THE British government's hankering for central control is evidently boundless. So much is evident in the decision by the Department for Education last week to set up a new organization to superintend educational standards in British universities. The idea is that, beginning in 1997, the new organization should carry out biennial inspections of university institutions. One of the objectives is said to be that the organization will ensure that degrees awarded by different institutions are of a "broadly comparable standard". The government's statement also says that the aim is to ensure "accountability for public funds" and respect for "university autonomy over academic standards".

Administratively, the new arrangement makes sense. Hitherto, responsibility for standards in higher education has been dispersed; the universities themselves have run the Higher Education Quality Council, while each of the four funding councils that allocate funds to different institutions rely on their own assessments in making their decisions. Universities will have only one invigilator breathing down their necks, which is no doubt why the chairman of the Committee of Vice-Chancellors and Principals described himself as "absolutely delighted" with the new arrangements. But he, and the universities, should think again.

Since the snap decision in 1990 that former polytechnics should be allowed to call themselves universities, the basis of the British government's relationship with universities has been the market principle that institutions must stand on their own feet, competing in the market for research funds and for students. The logic of that position is that there will in future be a variety of universities, offering courses with varied content and of varied difficulty to students of different aptitudes. Socially, that would be a prize worth having. Any system of higher education in which the participation rate approaches 30 per cent needs a substantial complement of second-rate universities - and, crucially, incentives by which those institutions will seek better things. The doctrine that "a degree is a degree is a degree...", for which British industry and politicians have been baying in recent months, is inimical to the diversity the British system needs.

\section{Technophobia and shares}

The London Stock Exchange, which thinks itself a citadel of capitalism, is behaving badly towards the Internet.

HERE is a fable of our times. Two smallish and technically alert British companies decided that it would be a good idea to use the Internet for selling shares in publicly registered British companies. One of them, called Sharelink, is a regular stockbroker that specializes in selling shares in small numbers to small investors, the other is a small Internet ser- vice provider based at Cambridge. The technical difficulties are not great and were quickly mastered, but the consortium needed a source of prices at which it would offer to buy or sell particular shares. Sharelink, in its capacity as a stockbroker, has access to the London Stock Exchange's electronic stream of trading prices, but properly recognized that it could not relay them to the Internet without breaching the exchange's copyright. So, for an interim period, the two sides made a deal: the exchange would be paid one penny ( $£ 0.01)$ for each item of its copyright information passed on to a potential buyer or seller of stock. Knowing that the secret of the Internet, that it is one thing to have a 'site' and quite another to know whether anybody will 'visit' it, the consortium arranged (two weeks ago) for a great party at which their venture would be publicized. And then the skies fell in.

To everybody's astonishment, the London Stock Exchange, which likes to think of itself as the world's most influential market in securities, repudiated its contract with the untried enterprise. When an official of Sharelink told a radio reporter that he considered the exchange's action unfair (or words to that effect), the exchange threatened to sue him for defamation. Goliath, it seemed, had been rattled by the mere appearance of an untried David on the scene, its own well-known distaste for small trades in stocks notwithstanding. But against a mounting background of ridicule, the exchange had second thoughts. In a weekend meeting ten days ago, the consortium and the exchange hammered out a new agreement; the use of the Internet for buying and selling shares will be allowed. So have reason and virtue triumphed over anti-competitive hankerings?

Not a bit of it. Another row, centred on an operation called Tradepoint, has arisen to take the place of the Sharelink scheme. That venture seeks to deal in very large, not very small, parcels of shares; its clients would be pension funds and other financial institutions. Its rationale is that, because the cost of dealing in large blocks of shares may be less than that of dealing in small bundles, it should be able to offer large institutions better prices than those obtainable from other stockbrokers. But that would offend against rule 4.18 of the 'rule book' with which all corporate members of the Stock Exchange must comply, that they do not offer more favourable prices than those offered by the Stock Exchange's own electronic datastream. Now the big, not the small, moneybags are up in arms.

Like other stock exchanges, the London Stock Exchange is a consortium of its stockbroker members; it seeks to protect their interests and to make a profit. Its almost instinctive reaction against both Sharelink and Tradepoint reflects the fear of most member firms that both initiatives will take business from them. But why was not the exchange itself, acting on behalf of its members, the first with the innovations it has been trying to squash? Sadly, this is the same stock exchange that, a year ago, lost close on $£ 100$ million of its members' money in devising a computer system to handle the accounting for stock sales. Lapsing into technophobia is understandable in the circumstances, but is hardly encouraging for those who pin their faith on the exchange's capacity to keep its preeminent position in a technical world. 